
Byrsonima Species

\author{
Pereira, V. V.; da Fonseca, F. A.; Bento, C. S. O.; Oliveira, P. M.; Rocha, L. \\ L.; Augusti, R.; Mendonça Filho, C. V.; Silva, R. R.
}

Rev. Virtual Quim., 2015, 7 (6), 2539-2548. Data de publicação na Web: 13 de novembro de 2015

http://www.uff.br/rvq

\begin{abstract}
Impressão Digital de Espécies de Byrsonima Utilizando Espectrometria de Massas com Ionização por Eletrospray
\end{abstract}

Resumo: Extratos de plantas apresentam uma grande diversidade química e, geralmente, requerem um tempo excessivo para o isolamento e caracterização de compostos. Análises de amostras complexas utilizando uma fonte de ionização por eletrospray acoplada à espectrometria de massa (ESI-MS) e a espectrometria de massa tandem (ESI-MS/MS) têm-se mostrado úteis na triagem inicial dessas amostras. Assim, é possível fazer a identificação de moléculas conhecidas sem isolamento prévio ou utilizando de outras técnicas analíticas auxiliares. Neste trabalho, os extratos secos de três espécies de Byrsonima foram dissolvidos em metanol, analisados através de injeção direta por ESI-MS e cada razão massa-carga $(\mathrm{m} / \mathrm{z})$ de interesse foi selecionada para análise de ESI-MS/MS. Impressão digital por ESI-MS mostrou uma distinção entre os constituintes químicos em cada uma das três espécies de Byrsonima analisadas e dados de ESI-MS/MS foram utilizados como ferramenta para ajudar na identificação dos principais componentes nos extratos de $B$. coccolobifolia, $B$. verbascifolia e $B$. intermedia. Mais especificamente, ácidos fenólicos, proantocianidinas e flavonoides foram detectados nas três espécies de Byrsonima estudadas.

Palavras-chave: Malpighiaceae; Byrsonima; ESI-MS; proantocianidinas; flavonoides.

\begin{abstract}
Extracts of plants presents a large chemical diversity and usually require extensive time for the isolation and characterization of the compounds. Analysis of complex samples by electrospray ionization source coupled to a mass spectrometry (ESI-MS) and tandem mass spectrometry (ESI-MS/MS) has proven to be useful tools for initial screening of these samples. Therefore, it allows identification of known molecules without isolation or use of other auxiliary analytical techniques. In this work, dried extracts of three Byrsonima species were dissolved in methanol, analyzed through direct injection by ESI-MS and each reason mass-to-charge $(\mathrm{m} / \mathrm{z})$ of interest was selected to ESI-MS/MS analysis. ESI-MS fingerprint showed a distinction among the chemical constituents in each of the three Byrsonima species and ESI-MS/MS data was used as a tool to help identify the main components of $B$. coccolobifolia, $B$. verbascifolia and $B$. intermedia extracts. More specifically, phenolic acids, proanthocyanidins and flavonoids were detected in the three Byrsonima species studied.
\end{abstract}

Keywords: Malpighiaceae; Byrsonima; ESI-MS; proanthocyanidins; flavonoids.

\footnotetext{
* Universidade Federal de Minas Gerais, Departamento de Química e Faculdade de Farmácia, CEP 31270-901, Belo Horizonte-MG, Brazil.

Mvncsviana@yahoo.com.br

DOI: $\underline{10.5935 / 1984-6835.20150152}$
}

Rev. Virtual Quim. |Vol 7| | No.6| |2539-2548| 


\title{
Electrospray Ionization Mass Spectrometry Fingerprint of the Byrsonima Species
}

\author{
Vinicius V. Pereira, ${ }^{\mathrm{a}, \mathrm{b}, *}$ Fabiana Aparecida da Fonseca, ${ }^{\mathrm{c}}$ Cecília S. O. \\ Bento, ${ }^{a}$ Patrícia M. Oliveira, ${ }^{d}$ Lílian Lúcia Rocha, ${ }^{e}$ Rodinei Augusti, ${ }^{a}$ Carlos \\ Victor Mendonça Filho, ${ }^{f}$ Roqueline R. Silva ${ }^{d}$ \\ a Universidade Federal de Minas Gerais, Departamento de Química, CEP 31270-901, Belo \\ Horizonte-MG, Brazil. \\ ${ }^{\mathrm{b}}$ Universidade Federal de Minas Gerais, Faculdade de Farmácia, CEP 31270-901, Belo \\ Horizonte-MG, Brazil. \\ c Universidade Federal de Minas Gerais, Escola de Engenharia, CEP 31270-901, Belo Horizonte- \\ MG, Brazil. \\ d Universidade Federal dos Vales do Jequitinhonha e Mucuri, Departamento de Química, CEP \\ 39100-000, Diamantina-MG, Brazil. \\ e Universidade Federal de Juiz de Fora, Departamento de Química, CEP 36036-900, Juiz de \\ Fora-MG, Brazil. \\ ${ }^{\mathrm{f}}$ Universidade Federal dos Vales do Jequitinhonha e Mucuri, Departamento de Ciências \\ Biológicas, CEP 39100-000, Diamantina-MG, Brazil. \\ * vncsviana@yahoo.com.br
}

Recebido em 29 de junho de 2015. Aceito para publicação em 8 de novembro de 2015

1. Introduction

2. Results and discussion

2.1. ESI-MS and ESI-MS/MS analysis

3. Conclusion

4. Experimental

4.1. Plant material and extraction

4.2. Electrospray ionization mass spectrometry (ESI-MS) and tandem mass spectrometry (ESI-MS/MS)

\section{Introduction}

Central region of Brazil is one of the most prominant biogeographic regions in the world, but it is also the most vulnerable. ${ }^{1}$ Many of the 160 families of species found are used as medicine by people. ${ }^{2}$ An ethnopharmacological survey carried out in the savanna regions showed a large number 
of plants that are used to treat gastric disorders. ${ }^{3}$ In the North and Northeastern regions of Brazil, different species of the Byrsonima (Malpighiaceae) are used not only in traditional medicine, but also as food in the form of juice, jellies, or liquors. ${ }^{4}$ The Byrsonima genus, consisting of approximately 150 species, is widely distributed throughout tropical America. ${ }^{5}$

Byrsonima species present different ethnomedicinal properties. The methanol extract from $B$. intermedia leaves presented gastroprotective, antimicrobial and antidiarrheal activities, supporting the traditional use to treat gastrointestinal disorders. ${ }^{6}$ High antimutagenic effect in the hydroalcoholic leaf extracts from $B$. intermedia and B. verbascifolia was related, indicating these plant extracts as potential sources of chemopreventive agents. However, the hydroalcoholic extract from $B$. coccolobifolia leaves showed mutagenic activity, suggesting caution in their use as medicinal plant. $^{7}$

Despite the medicinal use of Byrsonima species, there are few reports regarding their chemical constituents. ${ }^{8}$ Among the active principles found in medicinal plants, flavonoids, terpenes, and caffeic acid derivatives have attracted the most notable attention. ${ }^{9}$ Compounds of these classes have been analyzed by gas chromatography coupled to mass spectrometry, highperformance liquid chromatography, or capillary electrophoresis. ${ }^{9}$

Recently, electrospray ionization (ESI) has revolutionized the way that molecules are ionized and transferred to mass spectrometers for mass and structural analysis. ${ }^{10}$ Thus, a large applicability of mass spectrometry occurred because of its ability to analyze both small and large molecules of various polarities in a complex biological sample mixture. ${ }^{11}$ ESI-MS and ESI-MS/MS have gained widespread recognition, mainly due to its successful use in the dereplication analysis of bio-molecules. ${ }^{12}$

ESI-MS has been used as a fast and efficient fingerprinting method involving direct insertion of complex mixtures, such as those found in wines, ${ }^{13}$ petroleum, ${ }^{14}$ beers, ${ }^{15}$ propolis, ${ }^{16}$ and extracts containing natural compounds. ${ }^{17}$ In this study, direct injection of dried extracts of three Byrsonima species dissolved in methanol through ESI-MS was applied to quickly generate the fingerprint of the extracts from leaves of $B$. coccolobifolia, $B$. verbascifolia and $B$. intermedia and ESIMS/MS data were used as a tool to identify the main components of these extracts allowing an initial screening of them.

\section{Results and discussion}

\subsection{ESI-MS and ESI-MS/MS analysis}

Methanol extracts from Byrsonima species containing complex mixtures of polar compounds were investigated. Using classical phytochemical methods to isolate metabolites from plant extracts is generally time-consuming and sometimes lead to identification of known substances. This study analyzed the compounds present in the extracts from three Byrsonima species using ESI-MS methods, which showed to be useful to identify a large number of polar compounds.

Although experiments using both negative and positive ionization were performed, the negative ion mode of ESI provided the best results and with high sensitivity to the fingerprinting of all Byrsonima extracts analyzed. Positive ionization yielded more complex spectra with lower sensitivity and, moreover, the signal of the $[\mathrm{M}+\mathrm{H}]^{+}$ions was too low for MS/MS fragmentation analysis. Moreover, an exhaustive search in the literature about data on fragmentation in the positive ion mode was made and data for comparison were not found. Thus, all the identification of compounds was performed using electrospray ionization in negative ion mode (ESI(-)-MS).

Results of the ESI-MS and ESI-MS/MS suggest that the main constituents of the 
methanol extracts from B. coccolobifolia, $B$. verbascifolia and $B$. intermedia include phenolic acids, proanthocyanidins and flavonoids (Figure 1 and Table 1). Compounds of these classes are easily deprotonated and efficiently transferred to the gas phase as $[\mathrm{M}-\mathrm{H}]^{-}$ions.

In the ESI(-)-MS of the B. coccolobifolia extract (Figure 1-A), relatively intense and characteristic peaks of the extract could be observed within the $\mathrm{m} / \mathrm{z}$ range from 433 to 793 corresponding to deprotonated molecules. Anions at $m / z$ 433, 447, 463, 615, and 793 are most likely the $[\mathrm{M}-\mathrm{H}]^{-}$forms of flavonoids, while anions at $m / z 495$ and 577 are probably the $[\mathrm{M}-\mathrm{H}]^{-}$forms of digalloylquinic acid and proanthocyanidin dimer, respectively, as also indicated by ESIMS/MS (Table 1) and by comparisons with reported data in literature. ${ }^{18-20}$
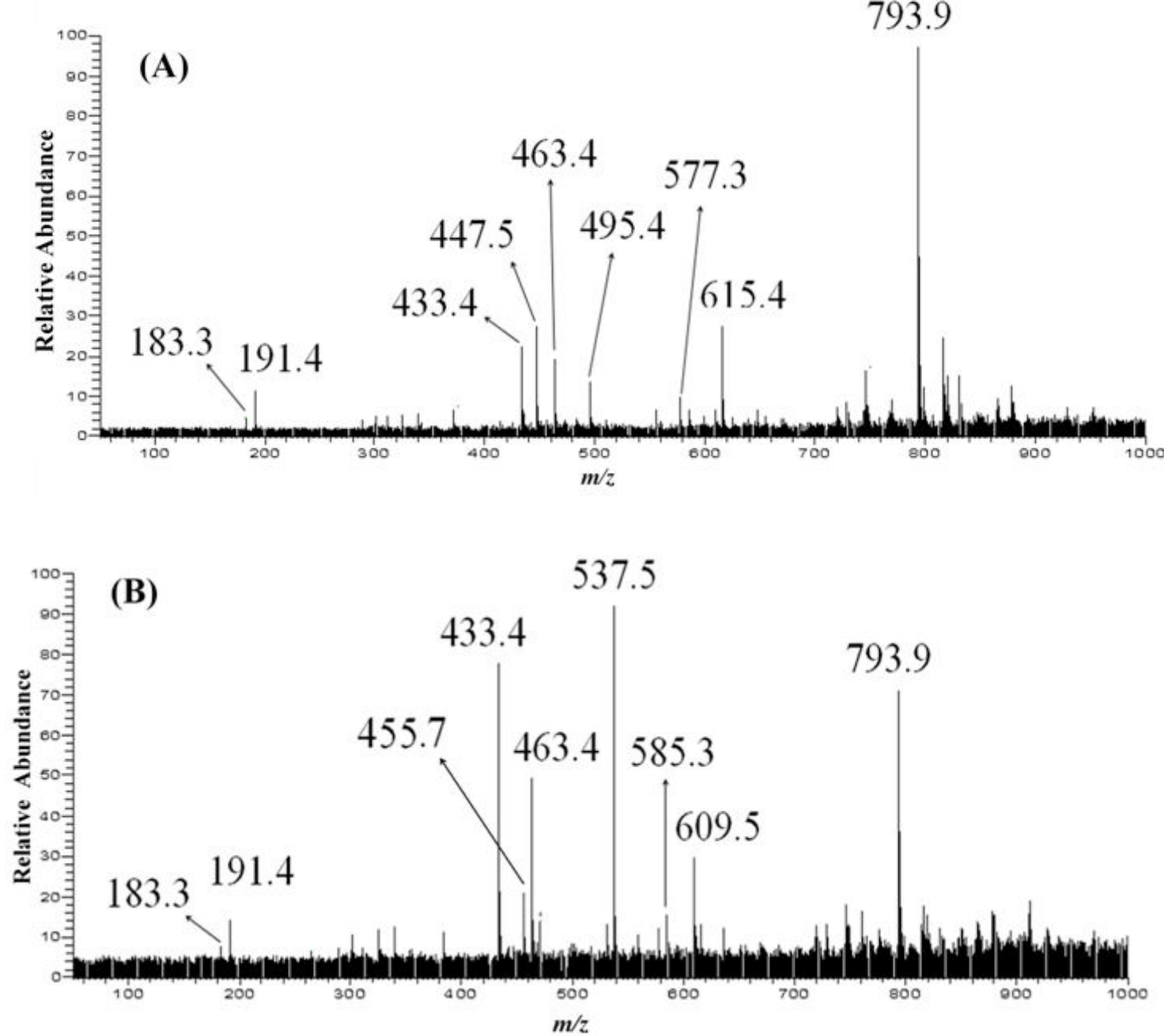


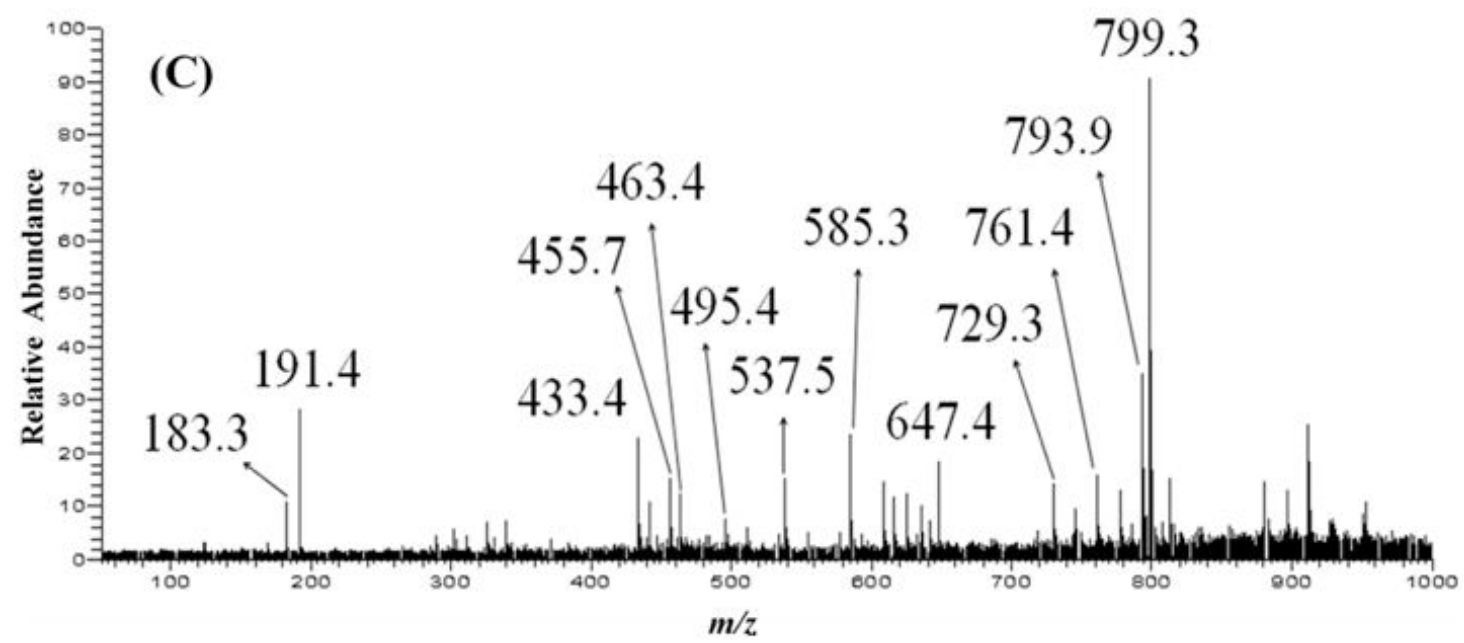

Figure 1. ESI(-)-MS fingerprint spectra representative of methanol extracts from $B$. coccolobifolia $(\mathrm{A}), \mathrm{B}$. verbascifolia $(\mathrm{B})$ and $B$. intermedia $(\mathrm{C})$

Table 1. Summary of MS data of the compounds obtained by ESI-MS and ESIMS/MS from the leaves of $B$. cocoolobifolia, B. verbascifolia and B. intermedia

\begin{tabular}{|c|l|c|l|}
\hline$[\text { M-H }]^{-}$ & \multicolumn{1}{|c|}{ MS/MS fragments } & Found in* & \multicolumn{1}{c|}{ Compound } \\
\hline Phenolic acids & Bco, Bve, Bin & Methyl gallate \\
\hline 183 & - & Bco, Bve, Bin & Quinic acid \\
\hline 191 & - & Bco & Digalloylquinic acid \\
\hline 495 & $477,343,325,169$ & Bin & Trigalloylquinic acid \\
\hline 647 & $495,477,343,325$ & Bin & Tetragalloylquinic acid \\
\hline 799 & $647,629,601,477$ & Bco & Dimer \\
\hline Proanthocyanidins & Bin & Monogalloyl dimer \\
\hline 577 & $559,451,425,407,289$ & Bco, Bve, Bin & Quercetin-O-pentose \\
\hline 729 & $711,577,559,451,425,407$ & Bco & Quercetin-O-deoxyhexose \\
\hline Flavonoids & Bve, Bin & Methyl (epi)catechin gallate \\
\hline 433 & 301,300 & Bco, Bve, Bin & Quercetin-O-hexose \\
\hline 447 & 301,300 & Bve, Bin & Amentoflavone \\
\hline 455 & 375,407 & Bve, Bin & Quercetin-O-pentose-galloyl \\
\hline 463 & 301,300 & Bve & Quercetin-O-disaccharide \\
\hline 537 & 375 & Bco & Quercetin-O-hexose-galloyl \\
\hline 585 & 433,301 & Bin & $\begin{array}{l}\text { Monoacyl diglycosilated quercetin } \\
\text { derivatives }\end{array}$ \\
\hline 609 & 463,301 & Bco, Bve, Bin & Amentoflavone derivative \\
\hline 615 & 463,301 & $609,463,301$ & \\
\hline 761 & & 537 &
\end{tabular}

*Bco: B. coccolobifolia, Bve: B. verbascifolia and Bin: B. intermedia.

MS/MS fragmentation of many flavonoids showed the formation of the diagnosis ion at $\mathrm{m} / \mathrm{z} 301$ and the anion radical at $\mathrm{m} / \mathrm{z} 300$,

which are characteristics of the deprotonated 
quercetin aglycone. For example, the ion at $\mathrm{m} / \mathrm{z} 615$ was assigned to the deprotonated molecule of quercetin-O-hexose-galloyl, whose fragmentation led to a peak at $\mathrm{m} / \mathrm{z}$ 463, $[\mathrm{M}-152-\mathrm{H}]^{-}$, and $\mathrm{m} / \mathrm{z}$ 301, [M-152$162-\mathrm{H}]^{-}$, corresponding to the sequential loss of galloyl and hexose residues. ${ }^{21}$

$M^{2}$ analysis of the deprotonated molecule at $m / z 495$ yields a product ion at $\mathrm{m} / \mathrm{z} 343,[\mathrm{M}-152-\mathrm{H}]^{-}$, due the loss of a galloyl moiety, indicating the presence of digalloylquinic acid. The formation of a base peak at $\mathrm{m} / \mathrm{z} 343$ and the product ion at $\mathrm{m} / \mathrm{z}$ 191 occur by the sequential loss of galloyl groups, $[\mathrm{M}-152-\mathrm{H}]^{-}$and $[\mathrm{M}-2 \times 152-\mathrm{H}]^{-}$, respectively. The product ion corresponding to a peak at $m / z 169$ was associated with the formation of the galloyl anion. ${ }^{18}$

The base peak of proanthocyanidin dimer at $\mathrm{m} / \mathrm{z} 577$ produced fragments of $\mathrm{m} / \mathrm{z} 451$ $\left([\mathrm{M}-126-\mathrm{H}]^{-}\right), m / z 425\left([\mathrm{M}-152-\mathrm{H}]^{-}\right)$and $m / z$ 407 ([M-152-18-H] $\left.]^{-}\right)$, which are products from a Retro-Diels-Alder (RDA) cleavage. However, as occurs in other mass spectrometry techniques, no differentiation between stereoisomers was possible and no information about the position and stereochemistry of the interflavonoid linkage was available. ${ }^{19}$

Figure 1-B shows the ESI(-)-MS representative of the $B$. verbascifolia extract. The anions of $m / z$ 433, 463 and 793 are also present in the fingerprinting spectra of the $B$. coccolobifolia (Figure 1-A); however, another four anions are clearly present in methanol extract from B. verbascifolia. The $[\mathrm{M}-\mathrm{H}]^{-}$ anions at $m / z$ 455, 537, 585 and 609 were attributed to methyl (epi)catechin gallate, amentoflavone, quercetin-O-pentose-galloyl and respectively. ${ }^{19,22}$ quercetin-O-disaccharide,

In the spectra of $B$. coccolobifolia and $B$. verbascifolia (Figures $1-A$ and $1-B$ ), the most intense ion was identified at $m / z$ 793. This anion had not been described in prior literature for any Byrsonima species, and its ESI-MS/MS analysis reveals only a product ion at $m / z 537$, suggesting that it could be a derivative of the biflavonoid amentoflavone.

Figure 1-C shows the ESI(-)-MS representative of the $B$. intermedia extract. In this spectrum, relatively intense and characteristic anions can be observed in the $\mathrm{m} / \mathrm{z}$ range from 183 to 799 . In fact, the ions at $m / z \quad 183$ and 191, corresponding respectively to methyl gallate and quinic acid, are present in the three Byrsonima species extracts. Furthermore, some anions present in the fingerprint spectrum of $B$. intermedia are also present in the spectra of $B$. coccolobifolia and B. verbascifolia $(\mathrm{m} / \mathrm{z} 433$, 455, 463, 537, 585 and 793). In addition, other anions at $m / z 647,729,761$, and 799 can easily be detected. Identification of many anions, observed in Figures 1-B and 1-C, was possible by means of a comparison with previously-reported ESI(-)-MS and ESI-MS/MS data. ${ }^{18-20,23}$

Anions at $m / z \quad 647$ and 799 were attributed to deprotonated molecules of galloylquinic acid derivatives. $\mathrm{MS}^{2}$ fragmentation of the ion at $\mathrm{m} / \mathrm{z} \quad 647$ (trigalloylquinic acid) yields product ions at $\mathrm{m} / \mathrm{z} 495$, [M-152-H] $]^{-}$, due to the loss of a galloyl moiety, as well as a small quantity of the ion at $m / z 477$, corresponding to a loss of gallic acid, [M-170-H]- Moreover, MS/MS spectrum of the precursor ion at $\mathrm{m} / \mathrm{z} 799$ (tetragalloylquinic acid) contained product ions at $m / z 647\left([\mathrm{M}-(1 \times 152)-\mathrm{H}]^{-}\right)$, reasonably assigned as the loss of a galloyl moiety. ${ }^{18,20}$ In the MS experiments, it was not possible to establish the complete characterization of these compounds, since there are numerous possibilities for the position isomers.

$\mathrm{MS}^{2}$ fragmentation of the ion at $\mathrm{m} / \mathrm{z} 761$, produced another ion at $m / z 609$ ([M-152$\mathrm{H}]^{-}$), indicating the loss of a galloyl unit. Sequential losses of deoxyhexose and hexose yielded product ions at $m / z 453$ ([M-152146-H] $\left.]^{-}\right)$and at $m / z 301$ ([M-152-146-162$\mathrm{H}]^{-}$). These data suggest the presence of monoacyl diglycosilated quercetin derivatives, as previously reported in $B$. crassa and B. fagifolia. ${ }^{5,20}$

Previous chemical investigation on 
Byrsonima species have resulted in the isolation of steroids, triterpenes, flavonoids, proanthocyanidins, galloylquinic acids and sulphonoglycolipids. ${ }^{4,19,21-23}$ Other studies reported the identification of gallic acid, pyrogallol, pyrocatechin and $\beta$-amyrin isolated from the roots of $B$. intermedia. ${ }^{25}$

Although chemical similarity has been observed among species of a genus, studies have shown that each plant contains characteristic substances. ${ }^{26}$ For example, anions identified at $m / z 537$ and 585 were previously detected in the ESI(-)-MS of leaf extracts of $B$. crassa and B. fagifolia. ${ }^{19,20}$ Conversely, these ions have been identified in the $B$. verbascifolia and $B$. intermedia species. The compounds methyl (epi)catechin gallate and quercetin-O-disaccharide, detected in their deprotonated forms at $\mathrm{m} / \mathrm{z}$ 455 and 609, respectively, have not been previously reported for both species. ${ }^{23}$ In a similar way, the compound detected as an anion of $m / z 793$ was also first detected in the leaves of $B$. coccolobifolia, $B$. verbascifolia and $B$. intermedia.

Thus, results obtained in this work indicate that $B$. coccolobifolia, $B$. verbascifolia and $B$. intermedia have similar flavonoids and phenolic acids when compared to other species of Byrsonima. Moreover, methyl gallate, quinic acid, quercetin-O-pentose and quercetin-O-hexose (detected at $\mathrm{m} / \mathrm{z}$ 183, 191, 433 and 463 in ESI(-)-MS analysis) were detected in the three Byrsonima species studied and could be useful as future chemical markers of these species.

\section{Conclusion}

ESI(-)-MS fingerprinting ensured a fast and powerful tool for the rapid identification of a complex mixture of known compounds present in the extracts from leaves of the three Byrsonima species. Moreover, ESI(-)MS technique allowed for the simultaneous detection of different constituents present in extract samples and can therefore provide a reliable distinction among the Byrsonima species. Finally, this approach suggests the identification of phenolic acids, proanthocyanidins and flavonoids in the leaves from $B$. coccolobifolia, $B$. verbascifolia and $B$. intermedia.

\section{Experimental}

\subsection{Plant material and extraction}

Leaves of B. coccolobifolia, B. verbascifolia and $B$. intermedia were collected at the Guapuruvu's reserve, located in Itamarandiba city (Minas Gerais, Brazil). This legal reserve is bounded by coordinates 170 44' $30^{\prime \prime}$ to 170 $43^{\prime} 00^{\prime \prime} \mathrm{S}$ and $42^{\circ}$ 46' $00^{\prime \prime}$ to $42^{\circ} 47^{\prime} 30^{\prime \prime} \mathrm{W}$. Plant materials were authenticated by Dr. Carlos Victor Mendonça Filho from the Biological Sciences Department of the Universidade Federal dos Vale do Jequitinhonha e Mucuri (Minas Gerais, Brazil). A voucher of each specimen $[B$. coccolobifolia (No. 1900), B. verbascifolia (No. 1899) and B. intermedia (No. 1898)] was deposited at the Herbarium of the same university.

After drying at room temperature, leaves of the three Byrsonima species were powdered and successively extracted with hexane, ethyl acetate and methanol by maceration, followed by filtration. The extracts were prepared at room temperature and concentrated under vacuum using a rotary evaporator to afford crude extracts from leaves. To this study, dried methanol extracts from Byrsonima species were submitted to the ESI-MS analysis.

\subsection{Electrospray ionization mass spectrometry (ESI-MS) and tandem mass spectrometry (ESI-MS/MS)}

MS analysis were performed on an LCQFleet instrument (ThermoScientific, San Jose, CA, USA) equipped with an ESI source. Mass spectra were acquired and processed 
using the software provided by the manufacturer (Xcalibur). Typical MS conditions were as follows: capillary voltage $11 \mathrm{~V}$, spray voltage 4 to $6.5 \mathrm{kV}$, tube lens offset at $110 \mathrm{~V}$, capillary temperature at 275 ${ }^{\circ} \mathrm{C}$, sheath gas $\left(\mathrm{N}_{2}\right)$ flow rate set to 9 (arbitrary units).

Dried extracts from Byrsonima species (approximately $1 \mathrm{mg}$ ) were dissolved in $1 \mathrm{~mL}$ of methanol, and the analysis were performed by means of direct infusion into the ESI source using a syringe pump at a flow rate of $15 \mu \mathrm{L} \mathrm{min}$. The full-scan range mass spectrum was acquired in $m / z$ 50-1000. For ESI-MS/MS analysis, the precursor ions were first isolated inside the ion trap and fragmented via collision-induced dissociation (CID) with gas helium. The relative collision energy was adjusted to yield product ions in quantifiable abundance.

\section{Acknowledgments}

Authors would like to thank Dr. C. L. Donnicci for his permission to use the LCQFleet instrument, which was purchased with financial support from FAPEMIG (PRONEX EDT 479/07), as well as FAPEMIG and CNPq for their financial support.

\section{References}

${ }^{1}$ Klink, C. A. Em First International Symposium on Tropical Savannas (Proceedings); Pereira, R.C., Nasser, L.C.B., eds.; EMBRAPA: Brasília, 1996.

${ }^{2}$ Mendonça, R. C.; Felfili, J. M.; Walter, B. M. T.; Silva, M. C.; Rezende, A. R.; Filguieras, T. S.; Nogueira, P. E. Em Cerrado Ambiente e Flora; Sano, S. M.; Almeida, S. P., eds.; EMBRAPA: Planaltina, 1998; Almeida, S. P.; Proença, C. E. B.; Sano, S. M.; Ribeiro, J. F.; Cerrado: Espécies Vegetais Úteis, EMBRAPA: Planaltina, 1998.
${ }^{3}$ Silva, S. R.; Silva, A. P.; Munhoz, C. B.; Silva Jr., M. C.; Medeiros, M. B. Guia de plantas do Cerrado utilizadas na chapada dos Veadeiros. WWF: Brasília, 2001.

${ }^{4}$ Sannomiya, M.; Fonseca, V. B.; da Silva, M. A.; Rocha, L. R. M.; dos Santos, L. C.; HirumaLima, C. A.; Souza-Brito, A. R. M.; Vilegas, W. Flavonoids and antiulcerogenic activity from Byrsonima crassa leaves extracts. Journal of Ethnopharmacoogy 2005, 97, 1. [CrossRef] [PubMed]

${ }^{5}$ Joly, A. B.; Botânica: Introdução à Taxonomia Vegetal, 12a. ed., Companhia Editora Nacional: São Paulo, 1998.

${ }^{6}$ Santos, R. C.; Kushima, H.; Rodrigues, C. M.; Sannomiya, M.; Rocha, L. R. M.; Bauab, T. M.; Tamashiro, J.; Vilegas, W.; Hiruma-Lima, C. A. Byrsonima intermedia A. Juss.: Gastric and duodenal anti-ulcer, antimicrobial and antidiarrheal effects in experimental rodent models. Journal of Ethnopharmacology 2012, 140, 203. [CrossRef] [PubMed]

${ }^{7}$ Espanha, L. G.; Resende, F. A.; Lima Neto, J. S.; Boldrin, P. K.; Nogueira, C. H.; Camargo, M. S.; Grandis, R. A.; Santos, L. C.; Vilegas, W.; Varanda, E. A. Mutagenicity and antimutagenicity of six Brazilian Byrsonima species assessed by the Ames test. BMC Complementary \& Alternative Medicine 2014, 14, 182. [CrossRef] [PubMed]

${ }^{8}$ Sannomiya, M.; Cardoso, C. R. P.; Figueiredo, M. E.; Rodrigues, C. M.; Dos Santos, L. C.; Dos Santos, F. V.; Serpeloni, J. M.; Cólus, I. M. S.; Vilegas, W.; Varanda, E. A. Mutagenicity and antimutagenicity of six Brazilian Byrsonima species assessed by the Ames test. Journal of Ethnopharmacology 2007, 112, 319. [CrossRef] [PubMed]

${ }^{9}$ a) Pietta, P. G.; Mauri, P. L.; Rava, A.; Sabbatini, G. Application of micellar electrokinetic capillary chromatography to the determination of flavonoid drugs. Journal of Crhomatography A 1991, 549, 367; [CrossRef] b) Pietta, P. G.; Mauri, P. L.; Gardana, C. Identification of the main flavonoids by use of chromatographic, electrophoretic, and 'on-line' spectral data. 
Journal of High Resolution Chromatography 1994, 17, 616; [CrossRef] c) Mauri, P. L.; Catalano, G.; Gardana, C.; Pietta, P. G. Analysis of Stevia glycosides by capillary electrophoresis. Electrophoresis 1996, 17, 367; [CrossRef] [PubMed] d) Merfort, I.; Pietta, P. G.; Mauri, P. L.; Zini, L.; Catalano, G.; Willuhn, G. Separation of Sesquiterpene Lactones from Arnicae Flos DAB 10 by Micellar Electrokinetic Chromatography. Phytochemical Analysis 1997, 8, 5; [CrossRef] e) Pietta, P.; Mauri, P.; Bauer, R. MEKC Analysis of Different Echinacea Species. Planta Medica 1998, 64, 649; [CrossRef] [PubMed] f) Steinke, B.; Muller, B.; Wagner, $\mathrm{H}$. Biological standardization of Ginkgo extracts. Planta Medica 1993, 59, 155. [CrossRef] [PubMed]

${ }^{10}$ Cole, R. B.; Electrospray and MALDI Mass Spectrometry, 2a. ed., Wiley: New York, 2010.

${ }^{11}$ Banerjee, S.; Mazumdar, S. Electrospray Ionization Mass Spectrometry: A Technique to Access the Information beyond the Molecular Weight of the Analyte. International Journal of Analytical Chemistry 2012, ID 282574, 1. [CrossRef]

12 a) Kotiaho, T. ; Eberlin, M. N.; Vainiotalo, P.; Kostiainen, R. Electrospray mass and tandem mass spectrometry identification of ozone oxidation products of amino acids and small peptides. Journal of the American Society for Mass Spectrometry 2000, 11, 526; [CrossRef] b) Rioli, V.; Gozzo, F. C.; Heimann, A. S.; Linardi, A.; Krieger, J. E.; Shida, C. S.; Almeida, P. C.; Hyslop, S.; Eberlin, M. N.; Ferro, E. S. Novel natural peptide substrates for endopeptidase 24.15, neurolysin, and angiotensin-converting enzyme. The Journal of Biological Chemistry 2003, 278, 8547; [CrossRef] [PubMed] c) Koch, K. J.; Gozzo, F. C.; Nanita, S. C.; Takats, Z.; Eberlin, M. N.; Cooks, R. G. Chiral transmission between amino acids: chirally selective amino acid substitution in the serine octamer as a possible step in homochirogenesis. Angewandte Chemie International Edition 2002, 41, 1721. [CrossRef]

${ }^{13}$ Cooper, H. J.; Marshall, A. G. Electrospray ionization Fourier transform mass spectrometric analysis of wine. Journal of Agricultural and Food Chemistry 2001, 49, 5710. [CrossRef] [PubMed]

${ }^{14}$ Hughey, C. A.; Rodgers, R. P.; Marshall, A. G. Resolution of 11,000 compositionally distinct components in a single electrospray ionization Fourier transform ion cyclotron resonance mass spectrum of crude oil. Analytical Chemistry 2002, 74, 4145. [CrossRef] [PubMed]

${ }^{15}$ a) Araújo, A. S.; Rocha., L. L.; Tomazela, D. M.; Sawaya, A. C. H. F.; Almeida, R. R.; Catharino, R. R.; Eberlin. M. N. Electrospray ionization mass spectrometry fingerprinting of beer. Analyst 2005, 130, 884; [CrossRef] [PubMed] b) Mauri, P.; Minaggio, M.; Simonetti, P.; Gardana, C.; Pietta, P. Analysis of saccharides in beer samples by flow injection with electrospray mass spectrometry. Rapid Communications in Mass Spectrometry 2002, 16, 743. [CrossRef] [PubMed]

${ }^{16}$ Sawaya, A. C. H. F.; Tomazela, D. M.; Cunha, I. B. S.; Bankova, V. S.; Marcucci, M. C.; Custodio, A. R.; Eberlin, M. N. Electrospray ionization mass spectrometry fingerprinting of propolis. The Analyst 2004, 129, 739. [CrossRef] [PubMed]

17 a) Mauri, P. L.; Pietta, P. Electrospray characterization of selected medicinal plant extracts. Journal of Pharmaceutical and Biomedical Analysis 2000, 23, 61; [CrossRef] b) $\mathrm{He}, \mathrm{X}$. On-line identification of phytochemical constituents in botanical extracts by combined high-performance liquid chromatographic-diode array detection-mass spectrometric techniques. Journal of Chromatography A 2000, 880, 203. [CrossRef]

${ }^{18}$ Rodrigues, C. M.; Rinaldo, D.; dos Santos, L. C.; Montoro, P.; Piacente, S.; Pizza, C.; Hiruma-Lima, C. A.; Souza Brito, A. R. M.; Vilegas, W. Metabolic fingerprinting using direct flow injection electrospray ionization tandem mass spectrometry for the characterization of proanthocyanidins from the barks of Hancornia speciosa. Rapid Communications in Mass Spectrometry 2007, 21, 1907. [CrossRef] [PubMed] 
${ }^{19}$ Sannomiya, M.; Montoro, P.; Piacente, S.; Pizza, C.; Brito, A. R. M. S.; Vilegas, W. Application of liquid chromatography/electrospray ionization tandem mass spectrometry to the analysis of polyphenolic compounds from an infusion of Byrsonima crassa Niedenzu. Rapid Communications in Mass Spectrometry 2005, 19, 2244. [CrossRef] [PubMed]

${ }^{20}$ Sannomiya, M.; dos Santos, L. C.; Carbone, V.; Napolitano, A.; Piacente, S.; Pizza, C.; Souza-Brito, A. R. M.; Vilegas, W. Liquid chromatography/electrospray ionization tandem mass spectrometry profiling of compounds from the infusion of Byrsonima fagifolia Niedenzu. Rapid Communications in Mass Spectrometry 2007, 21, 1393. [CrossRef] [PubMed]

${ }^{21}$ a) Cuyckens, F.; Claeys, M. Determination of the glycosylation site in flavonoid mono-Oglycosides by collision-induced dissociation of electrospray-generated deprotonated and sodiated molecules. Journal of Mass Spectrometry 2005, 40, 364; [CrossRef] [PubMed] b) Hvattum, E.; Ekeberg, D. Study of the collision-induced radical cleavage of flavonoid glycosides using negative electrospray ionization tandem quadrupole mass spectrometry. Journal of Mass Spectrometry 2003, 38, 43. [CrossRef] [PubMed]

${ }^{22}$ Lima, Z. P.; Santos, R. C.; Torres, T. U.; Sannomiya, M.; Rodrigues, C. M.; Santos, L. C.; Pellizzon, C. H.; Rocha, L. R. M.; Vilegas, W.; Souza-Brito, A. R. M.; Cardoso, C. R. P.; Varanda, E. A.; Moraes, H. P.; Bauab, T. M.; Carli, C.; Carlos, I. Z.; Hiruma-Lima, C. A. Byrsonima fagifolia: an integrative study to validate the gastroprotective, healing, antidiarrheal, antimicrobial and mutagenic action. Journal of Ethnopharmacology 2008, 120, 149. [CrossRef] [PubMed]

${ }^{23}$ Bejar, E.; Amarquaye, A.; Che, C. T.; Malone, M. H.; Fong, H. H. S. Constituents of Byrsonima crassifolia and their Spasmogenic Activity. International Journal of Pharmacognosy 1995, 33, 25. [CrossRef]

${ }^{24}$ Bastos, D. H. M.; Saldanha, L. A.; Catharino, R. R.; Sawaya, A. C. H. F.; Cunha, I. B. S.; Carvalho, P. O.; Eberlin, M. N. Phenolic antioxidants identified by ESI-MS from Yerba maté (Ilex paraguariensis) and green tea (Camelia sinensis) extracts. Molecules 2007, 12, 423. [CrossRef] [PubMed]

25 a) Rastrelli, L.; de Tommasi, N.; Berger, I.; Caceres, A.; Saravia, A.; de Simone, F. Glycolipids from Byrsonima crassifolia. Phytochemistry 1997, 45, 647; [CrossRef] b) Mendes, C. C.; Cruz, F. G.; David, J. M.; Nascimento, I. P.; David, J. P. Triterpenos esterificados com ácidos graxos e ácidos triterpênicos isolados de Byrosonima microphylla. Química Nova 1999, 22, 185. [CrossRef]

${ }^{26}$ a) Sannomiya, M.; Rodrigues, C. M.; Coelho, R. G.; Santos, L. C.; Hiruma-Lima, C. A.; Souza-Brito, A. R. M.; Vilegas, W. Application of preparative high-speed counter-current chromatography for the separation of flavonoids from the leaves of Byrsonima crassa Niedenzu (IK). Journal of Chromatography A 2004, 1035, 47; [CrossRef] [PubMed] b) da Silva, J. B. Gallic acid, pyrogallol and pyrocatechol in the roots of Byrsonima intermedia Ad. Jussieu, form Latifolia grisebach. Revista da Faculdade de Farmácia e Bioquímica da Universidade de São Paulo 1970, 8, 187. [PubMed] 